\title{
Neuropeptide Y Impairs Retrieval of Extinguished Fear and Modulates Excitability of Neurons in the Infralimbic Prefrontal Cortex
}

\author{
@Lauren L. Vollmer, ${ }^{1,3}$ @Sarah Schmeltzer, ${ }^{3}$ Jennifer Schurdak, ${ }^{1}$ Rebecca Ahlbrand, ${ }^{1}$ Jennifer Rush, ${ }^{1}$ \\ Charles M. Dolgas, ${ }^{1}$ Mark L. Baccei, ${ }^{2,3}$ and Renu Sah ${ }^{1,3,4}$ \\ Departments of ${ }^{1}$ Psychiatry and Behavioral Neuroscience and ${ }^{2}$ Anesthesiology and ${ }^{3}$ Neuroscience Graduate Program, University of Cincinnati, Cincinnati, \\ Ohio 45221, and ${ }^{4}$ Veterans Administration Medical Center, Cincinnati, Ohio 45220
}

\begin{abstract}
Neuropeptide Y (NPY), a 36 aa peptide, regulates stress and emotional behaviors. Preclinical and clinical studies support an association of NPY with trauma-evoked syndromes such as posttraumatic stress disorder (PTSD), although the exact contribution of NPY is not clear. In the current study, we examined functional attributes of NPY in the infralimbic (IL) cortex, an area that regulates fear memories and is reported to be hypoactive in PTSD. Carriers of NPY gene polymorphism rs16147 have been reported to have elevated prefrontal NPY expression. Infusion of NPY into the IL cortex in rats significantly impaired fear extinction memory without affecting conditioned fear expression or acquisition of extinction. Neuroendocrine stress response, depression-like behavior, and working memory performance were not affected by NPY infusion into the IL. The NPY Y 1 receptor antagonist BIBO3304 completely abolished NPY effects on fear extinction retrieval. $Y_{1}$ receptor expression was localized on CaMKII-positive pyramidal projection neurons and GAD67-positive interneurons in the IL. Patch-clamp recordings revealed increased inhibitory synaptic transmission onto IL projection neurons in the presence of NPY. Thus, NPY dampens excitability of IL projection neurons and impairs retrieval of extinction memory by inhibiting consolidation of extinction. Of relevance to PTSD, elevation of prefrontal NPY attributable to the genetic polymorphism rs16147 may contribute to IL hypoactivity, resulting in impaired extinction memory and susceptibility to the disorder.
\end{abstract}

Key words: extinction; fear; infralimbic; Neuropeptide Y; prefrontal; Y1

Significance Statement

Neuropeptide Y (NPY), a stress modulatory transmitter, is associated with posttraumatic stress disorder (PTSD). Contribution of NPY to PTSD symptomology is unclear. PTSD patients have reduced activity in the infralimbic (IL) subdivision of the medial prefrontal cortex (mPFC), associated with compromised extinction memory. No information exists on fear modulation by NPY in the IL cortex, although NPY and NPY receptors are abundant in these areas. This study shows that IL NPY inhibits consolidation of extinction, resulting in impaired retrieval of extinction memory and modulates excitability of IL projection neurons. In addition to providing a novel perspective on extinction memory modulation by NPY, our findings suggest that elevated mPFC NPY in gene polymorphism rs16147 carriers or after chronic stress could increase susceptibility to PTSD.

\section{Introduction}

Neuropeptide Y (NPY), a 36 aa peptide, is widely expressed in the CNS (Adrian et al., 1983; Allen et al., 1983) and regulates physiological and behavioral responses such as stress and anxiety, fear, learning and memory, control of blood pressure, and sympathetic activity (Heilig and Widerlöv, 1995; Eaton et al., 2007).

\footnotetext{
Received Nov. 25, 2013; revised Nov. 23, 2015; accepted Dec. 16, 2015.

Author contributions: L.L.V., M.L.B., and R.S. designed research; L.L.V., S.S., J.S., R.A., J.R., C.M.D., M.L.B., and R.S. performed research; L.L.V., S.S., M.L.B., and R.S. analyzed data; L.L.V., M.L.B., and R.S. wrote the paper.

This work was supported by VA Merit Award Grant BX001075-01 (R.S.). We thank Dr. James P. Herman for helpful comments. The technical assistance of Cristina Weiner, Meeta Bhardwaj, and Ben Packard is also acknowledged.

The authors declare no competing financial interests.
}

NPY has gained attention as a stress resiliency transmitter associated with posttraumatic stress disorder (PTSD) (Wu et al., 2011; Sah and Geracioti, 2013), although the exact contributions of the peptide to PTSD pathophysiology are still unclear.

Regulation of fear memories is pertinent to PTSD pathophysiology (Parsons and Ressler, 2013). An inability to suppress or extinguish fear memories may sustain pathologically high levels

Correspondence should be addressed to Dr. Renu Sah, Department of Psychiatry and Behavioral Neuroscience, University of Cincinnati, Metabolic Disease Institute, 2170 East Galbraith Road, Cincinnati, OH 45237. E-mail: sahr@uc.edu.

DOI:10.1523/JNEUROSCI.4955-13.2016

Copyright $\odot 2016$ the authors $\quad 0270-6474 / 16 / 361306-10 \$ 15.00 / 0$ 
of fear in patients with PTSD years after the trauma (Milad et al., 2009; Jovanovic et al., 2010). Increasing evidence supports a primary role of the infralimbic subdivision (IL) of the medial prefrontal cortex [mPFC; ventromedial PFC (vmPFC in humans)] in fear extinction and retrieval (Milad and Quirk, 2002). Importantly, impaired retrieval of extinction observed in PTSD subjects is associated with reduced activation in the vmPFC (Milad et al., 2009). NPY and NPY receptors, particularly the $Y_{1}$ receptor $\left(\mathrm{Y}_{1} \mathrm{R}\right)$, are abundantly expressed in cortical areas (Dumont et al., 1996) where they may impact synaptic excitability and function. Interestingly, higher prefrontal NPY expression is observed in individuals carrying the rs $16147 \mathrm{~T}>\mathrm{C}$ polymorphism in the NPY gene, which is associated with negative affect in high adversity (Sommer et al., 2010). In a rodent model of PTSD-like behaviors, we have shown a persistent elevation in prefrontal NPY mRNA and peptide that correlate temporally with exaggerated fear reinstatement and extinction deficits (McGuire et al., 2010, 2011). NPY has potent inhibitory effects on neuronal excitability and has been shown to have strong anticonvulsant actions in neocortical circuits (Bacci et al., 2002). Studies to date on NPY regulation of fear have primarily focused on the amygdala (Gutman et al. 2008; Verma et al., 2015). However, no information exists currently on the functional contributions of NPY in the mPFC.

Given the relevance of the IL cortex in PTSD pathophysiology, we investigated the effects of IL NPY infusion on fear extinction and retrieval, a PTSD-relevant outcome. We also performed patch-clamp recordings from IL projection neurons in the presence of NPY to determine effects of NPY on neuronal excitability within this area. Furthermore, IL NPY effects on other mPFC regulated outcomes, such as the hypothalamic-pituitary-adrenal (HPA) response, forced swim test (FST) behavior, and working memory, were also measured (Radley et al., 2006; Wulsin et al., 2010; Butts et al., 2011). HPA dysfunction, depression, and cognitive deficits are often comorbid with PTSD (McNally, 2006; Vythilingam et al., 2010). Moreover, recent work suggests a role of the IL cortex in HPA regulation and depression-like behaviors (McKlveen et al., 2013). Immunohistochemical studies were also performed to localize NPY and NPY Y ${ }_{1}$ receptor expression in IL neurons.

\section{Materials and Methods}

\section{Subjects}

A total of 210 male Sprague Dawley rats (275-300 g; Harlan Laboratories) were used in the study. Rats were housed in polyethylene cages and maintained on a $12 \mathrm{~h}$ light/dark schedule with ad libitum access to standard laboratory rat chow and water. Experiments were conducted during the light phase. All procedures were approved by the Institutional Animal Care and Use Committee of the University of Cincinnati. Separate cohorts of animals were used for each experiment as follows: (1) NPY dose response (48; 12 per group); (2) NPY consolidation (24; 12 per group); (3) $\mathrm{Y}_{1}$ antagonist experiment ( $n=48$; 12 per group); (4) HPA $(n=24 ; 12$ per group); (5) FST ( $n=24 ; 12$ per group); (6) delayed spatial win-shift (DSWS; $n=24 ; 12$ per group); (7) electrophysiology $(n=13)$; and (8) immunohistochemistry $(n=5)$. For behavioral experiments, only data from IL hits was used for statistical analyses (see section for details).

\section{Surgery}

Rats were anesthetized with ketamine/xylazine $(80 / 12 \mathrm{mg} / \mathrm{kg})$ and placed in the stereotaxic apparatus. The skin was retracted and the cranium was exposed and scraped. Twenty-six gauge bilateral guide cannulas (Plastics One) were implanted over the IL cortex using the following coordinates: $\pm 2.7 \mathrm{~mm}$ anteroposterior, $\pm 0.6 \mathrm{~mm}$ mediolateral, and $-5.1 \mathrm{~mm}$ dorsoventral from bregma (Paxinos and Watson, 1998). Cannulas were secured to the skull with stainless steel screws and dental cement. Rats were handled daily for 2 weeks, and cannulas were manipulated to habituate animals to the injection procedure. Obturators were removed and injector tips were placed into the guide cannulas. Injector tips had a $3.1 \mathrm{~mm}$ projection beyond the $2 \mathrm{~mm}$ guide cannulas. After infusion, injectors were left in place for $1 \mathrm{~min}$ to allow for the drug to diffuse.

\section{Drugs and infusions}

Timing of NPY administration at pre-extinction and post-extinction training were selected based on recent studies showing the necessity of the IL cortex during extinction training and extinction consolidation but not during retrieval of extinction (Do-Monte et al., 2015). NPY (Bachem) or artificial CSF (aCSF) was administered 30 min before extinction training on Day 2 (Fig. $1 C$ ) or immediately after extinction training (Fig. 1E). For dose response, we tested NPY at 3, 10, and 30 pmol/0.2 $\mu \mathrm{l}$ per side. The 10 pmol NPY dose was selected for all other experiments because it has also been used previously for NPY effects on fear potentiated startle extinction and stress via the basolateral amygdala (BLA; Gutman et al., 2008; Sajdyk et al., 2008). The NPY Y ${ }_{1}$ R antagonist BIBO3304 ( $N$-[(1R)-1-[[[[4-[[(aminocarbonyl)amino]methyl]phenyl] methyl]amino]carbonyl]-4-[(aminoiminomethyl)amino]butyl]-á-phenyl-benzeneacetamide ditrifluoroacetate (BIBO); Tocris Bioscience, R\&D Systems] was infused at $200 \mathrm{pmol} / 0.2 \mu \mathrm{l}$ per side, $10 \mathrm{~min}$ before NPY for antagonism experiments. This BIBO dose was selected because it effectively blocked NPY-facilitated extinction of fear-potentiated startle via BLA infusion (Gutman et al., 2008). For assessment of drug spread, we injected a few rats with fluorescent NPY (FAM-NPY; Phoenix Peptides), and fluorescence was assessed in hits verified by tracts within the IL coordinates (Fig. 1B). NPY was administered 30 min before restraint stress (HPA), FST exposure, or retrieval testing phase of the DSWS task.

\section{Behavioral procedures}

Fear conditioning. Auditory fear conditioning, extinction, and retrieval of extinction were performed in operant chambers housed in soundattenuated isolation cabinets (CleverSys) throughout all phases of the experiment. The floor of the chambers consisted of stainless steel grid bars that delivered scrambled electric footshocks. Between each run, the grid, floor trays, and chamber walls were wiped with $10 \%$ ethanol and allowed to dry completely.

The auditory conditioning-extinction-retrieval procedure was adapted from a previous study (Sierra-Mercado et al., 2011). Briefly, on Day 1 , all animals underwent training that consisted of five habituation tones [ $70 \mathrm{~dB}, 2 \mathrm{kHz}, 30 \mathrm{~s}$ with a 3 min intertrial interval (ITI)] that were followed by seven conditioning tones that coterminated with footshocks $(0.6 \mathrm{~mA}, 0.5 \mathrm{~s})$. On Day 2, animals were returned to the chambers for extinction training that consisted of exposure to 15 tones $(70 \mathrm{~dB}, 2 \mathrm{kHz}$, $30 \mathrm{~s}, 3 \mathrm{~min}$ ITI) in the absence of footshocks. On Day 3 , rats received 10 tones $(70 \mathrm{~dB}, 2 \mathrm{kHz}, 30 \mathrm{~s}$ with a $3 \mathrm{~min}$ ITI) to measure retrieval of extinguished fear. Conditioned fear responses to tone were measured as percentage freezing during $30 \mathrm{~s}$. Freezing, defined as the absence of all movements except respiration, was measured from saved videos by observers blinded to treatment. Reported data analyses were performed on hand-scored data.

FST. The behavioral apparatus was a Plexiglas cylinder $45 \mathrm{~cm}$ high and $20 \mathrm{~cm}$ in diameter filled with $31 \mathrm{~cm}$ of water $\left(30-33^{\circ} \mathrm{C}\right)$. Rats were placed in the cylinder for $10 \mathrm{~min}$, and the session was videotaped. Scoring was done by an observer blind to the treatment conditions. The behavior was scored every $5 \mathrm{~s}$, and the total counts for immobility behavior, which is defined as the rat not making any active movements or floating in the water without struggling, were assessed for the session and summed for each animal and averaged within each treatment group.

DSWS procedure. The DSWS task was adapted from previous studies with modifications (Floresco et al., 1997; Butts et al., 2011) and performed on an eight arm radial arm maze (RAM). After recovery from surgery, rats were food restricted to $80 \%$ of their ad libitum feeding before training for the DSWS procedure. The procedure involved three phases: habituation, training trials, and retrieval testing performance after aCSF and NPY. After recovery from cannula surgery, animals were habituated to the maze environment for $2 \mathrm{~d}$ (Days 1-2). Subsequent training trials were given once daily (Days 3-14). Each trial consisted of an acquisition phase and retrieval phase, separated by a delay period. 
A

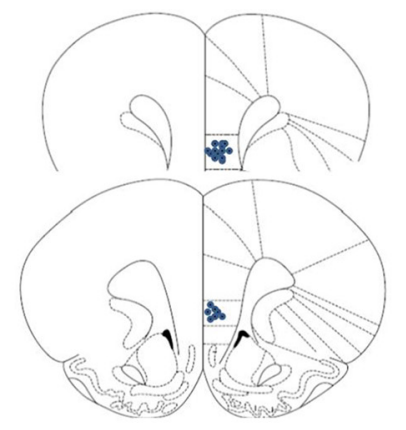

C

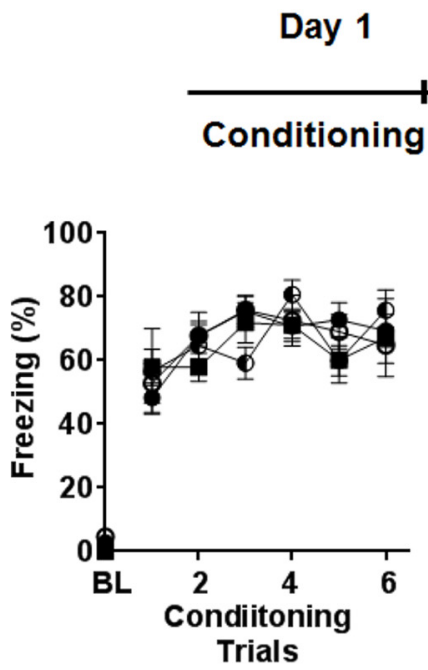

D

B
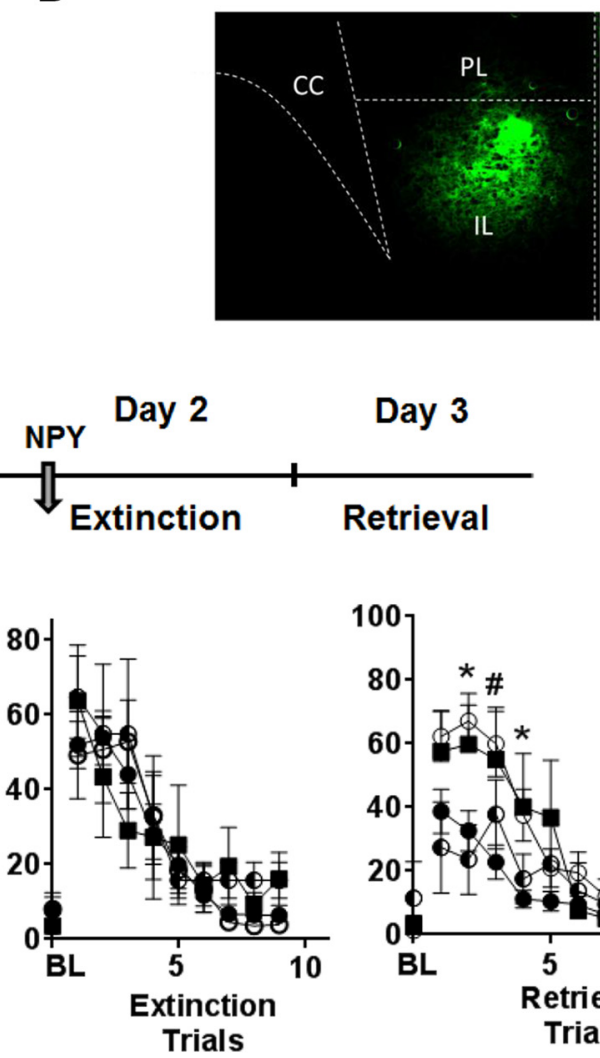

Day 3

Day 2

Extinction

Retrieval

E

Day 1

Day 2
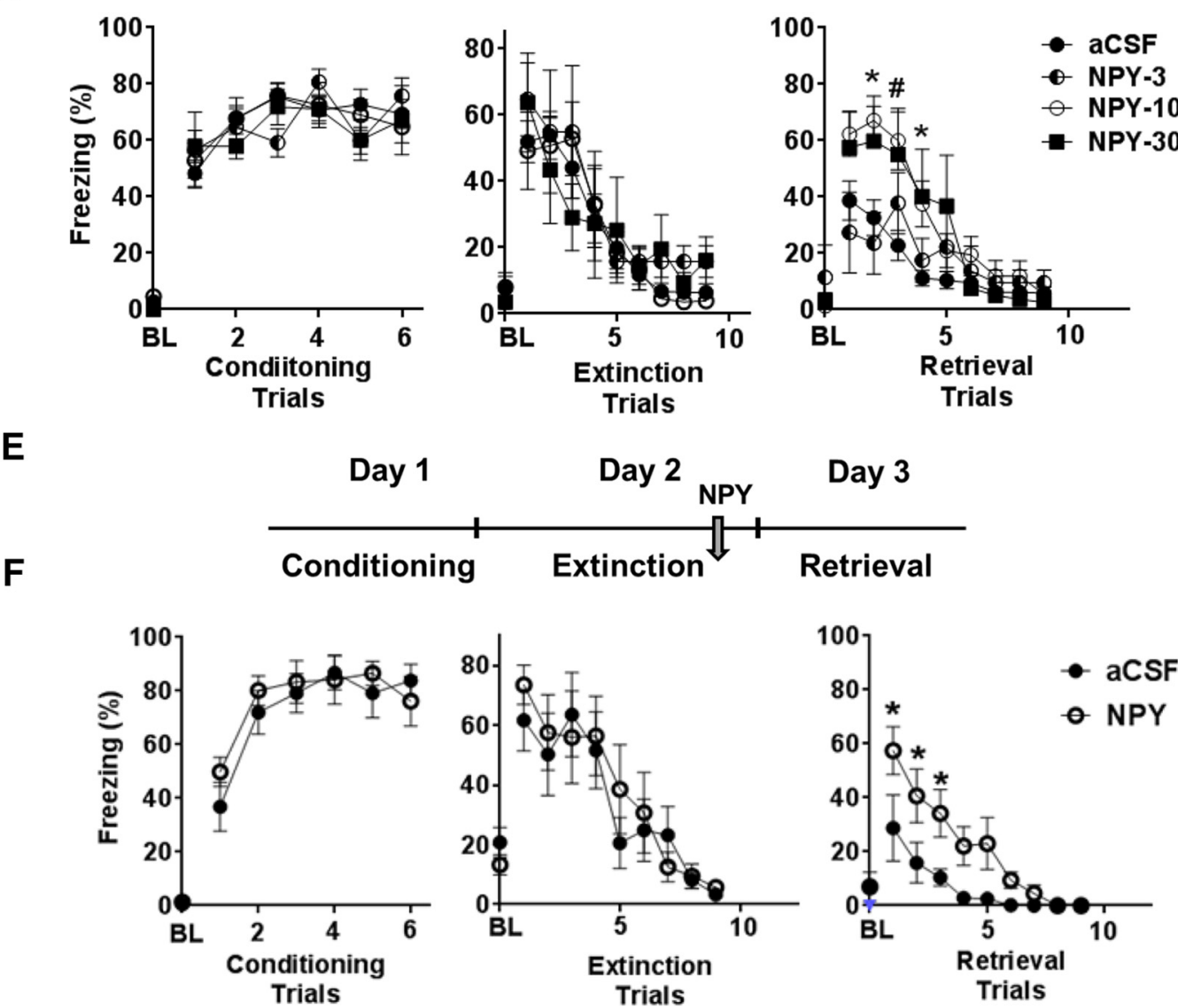

Figure 1. NPY infusion into the IL cortex impairs retrieval of extinction. $\boldsymbol{A}$, Representative illustration showing location of cannula placements in the IL cortex based on histological assessment. Coronal sections represent coordinates $+3.2 \mathrm{~mm}$ (top) and $+2.7 \mathrm{~mm}$ (bottom) relative to bregma. $\boldsymbol{B}$, Image showing the spread of fluorescent labeled NPY (FAM-NPY) within the IL subdivision of the mPFC. C, Timeline of the experiment showing infusion of NPY before extinction training on Day 2. D, Freezing response to tone for rats infused with aCSF $(n=12)$ or NPY $(3,10$, and $30 \mathrm{pmol} / 0.2$ $\mu l ; n=6-8)$. Rats infused with 10 or $30 \mathrm{pmol}$ NPY showed significantly higher freezing compared with aCSF rats during extinction retrieval on Day 3 , as noted by higher levels of freezing (right). No significant difference in percentage freezing was noted during conditioning (left) or extinction training (middle). $E$, Schematic for post-extinction training infusion of NPY. $F$, Infusion of NPY (10 pmol) into the IL post-extinction acquisition significantly impaired retrieval of extinguished fear compared with the aCSF-infused group ( $n=7$ per group). Data shown are mean \pm SEM; ${ }^{*} p<0.05$ versus aCSF and 3 pmol NPY (Fig. 1D) or aCSF (Fig. 1F) group. For conditioning, data on post-shock freezing for shocks 1- 6 are shown. For extinction and retrieval, data from tones $1-9$ are shown. Magnitude of freezing plateaued at these time points, and no additional changes in freezing were observed in subsequent trials. PL, Prelimbic cortex; CC, corpus callosum. BL represents baseline freezing during 2 min before the delivery of conditioning, extinction, or retrieval trials.

During the acquisition phase, a set of four arms were chosen and blocked. Food pellets (Research Diets) were placed in the food cups of the four remaining open arms. Each rat was given 5 min to retrieve the pellets from the four open arms and then was returned to its home cage for the delay period. During the retrieval phase of each daily trial, all arms were opened, but only the arms that were blocked previously contained food. Rats were allowed a maximum of 5 min during the retrieval phase. Errors during the retrieval phase were scored as any entry into a nonbaited arm and were divided into two error subtypes: (1) "across-phase" errors that were defined as an entry into an arm that had been entered previously during the acquisition phase; and (2) "within-phase" errors defined as any reentry into an arm that had been entered in the retrieval phase. The initial delay period was $5 \mathrm{~min}$ until the rats reached criterion (one error or less during retrieval phase) for at least 2 consecutive days. The delay 
period was then increased to $30 \mathrm{~min}$ for another $2 \mathrm{~d}$ to confirm criterion of one or less error. On the final day of testing, aCSF or NPY was administered before the delay period, and errors during retrieval phase were recorded.

\section{HPA axis response to acute stressor}

Peripheral blood was collected from the tail vein at 15, 30, 60, and 120 min from initiation of restraint (30 min). Plasma corticosterone was measured using the ImmuChem Double Antibody Corticosterone ${ }^{125} \mathrm{I}$ RIA kit (MP Biomedicals). Corticosterone concentration was calculated using AssayZap software (Biosoft).

\section{Patch-clamp recordings of IL-PFC neurons}

Male Sprague Dawley rats (postnatal days 25-32) were anesthetized deeply with sodium pentobarbital $(30 \mathrm{mg} / \mathrm{kg}$ ) and perfused with ice-cold dissection solution consisting of the following (in $\mathrm{mm}$ ): 250 sucrose, 2.5 $\mathrm{KCl}, 25 \mathrm{NaHCO}_{3}, 1.0 \mathrm{NaH}_{2} \mathrm{PO}_{4}, 6 \mathrm{MgCl}_{2}, 0.5 \mathrm{CaCl}_{2}$, and 25 glucose (bubbled with $95 \% \mathrm{O}_{2} / 5 \% \mathrm{CO}_{2}$ ). The brain was removed rapidly, blocked, and immersed in low-melting-point agarose (3\% in above solution; Invitrogen). Transverse slices $(300 \mu \mathrm{m})$ containing the IL-PFC (Paxinos and Watson, 1998) were cut using a Vibroslice tissue slicer (HA-752; Campden Instruments). The slices were placed in a chamber filled with oxygenated dissection solution for $30 \mathrm{~min}$ and then allowed to recover for $\geq 1 \mathrm{~h}$ at room temperature (RT) in an oxygenated aCSF solution containing the following (in $\mathrm{mM}$ ): $125 \mathrm{NaCl}, 2.5 \mathrm{KCl}, 25$ $\mathrm{NaHCO}_{3}, 1.0 \mathrm{NaH}_{2} \mathrm{PO}_{4}, 1.0 \mathrm{MgCl}_{2}, 2.0 \mathrm{CaCl}_{2}$, and 25 glucose. After recovery, slices were transferred to a submersion-type recording chamber (RC-22; Warner Instruments), mounted on the stage of an upright microscope (BX51WI; Olympus), and perfused with oxygenated aCSF at a rate of $3-6 \mathrm{ml} / \mathrm{min}$ at $31-33^{\circ} \mathrm{C}$.

Patch electrodes were constructed from thin-walled single-filamented borosilicate glass ( $1.5 \mathrm{~mm}$ outer diameter; World Precision Instruments) using a microelectrode puller (P-97; Sutter Instruments). Pipette resistances ranged from 3 to $5 \mathrm{M} \Omega$, and seal resistances were $>1 \mathrm{G} \Omega$. Voltageclamp recordings of EPSCs used an intracellular solution containing the following: $130 \mathrm{~mm}$ Cs-gluconate, $10 \mathrm{~mm} \mathrm{CsCl}, 10 \mathrm{~mm}$ HEPES, $11 \mathrm{~mm}$ EGTA, $1.0 \mathrm{~mm} \mathrm{CaCl}_{2}$, $2.0 \mathrm{~mm} \mathrm{MgATP}, 1 \mathrm{~mm}$ QX-314, and $0.2 \%$ biocytin. IPSCs were recorded with an intracellular solution containing the following: $130 \mathrm{~mm} \mathrm{CsCl}, 2$ mм $\mathrm{MgCl}_{2}, 10$ mм HEPES, 2 mм Na 2 ATP, $0.4 \mathrm{~mm}$ $\mathrm{Na}_{3} \mathrm{GTP}, 1 \mathrm{~mm}$ QX-314, and $0.2 \%$ biocytin.

Using infrared-differential interference contrast optics, layer $\mathrm{V}$ pyramidal neurons within the IL-PFC were located visually based on their large somata and the presence of a prominent apical dendrite extending toward the pial surface (Bacci et al., 2002). Whole-cell patch-clamp recordings were obtained from these neurons using a Multiclamp 700B amplifier (Molecular Devices) at a holding potential of $-70 \mathrm{mV}$. Synaptic responses were evoked electrically $(10-35 \mu \mathrm{A}, 100 \mu \mathrm{s}$ at $0.10 \mathrm{~Hz})$ via a second patch electrode placed within layer II/III, which was connected to a constant-current stimulator (Master-8; A.M.P.I.). AMPARmediated EPSCs were isolated pharmacologically in the presence of 25 $\mu \mathrm{M}$ AP-5, $10 \mu \mathrm{M}$ gabazine, and $0.5 \mu \mathrm{M}$ strychnine, whereas $\mathrm{GABA}_{\mathrm{A}} \mathrm{R}-$ mediated IPSCs were recorded in the presence of $25 \mu \mathrm{M} \mathrm{AP-5,} 10 \mu \mathrm{M}$ NBQX, and $0.5 \mu \mathrm{M}$ strychnine. After 3 min of baseline recording, NPY (1 $\mu \mathrm{M})$ was bath applied for $5 \mathrm{~min}$. Selection of $1 \mu \mathrm{M}$ NPY concentration was based on a number of previous in vitro electrophysiological studies that used this concentration to examine potential effects on the excitability of cortical, hippocampal, and amygdalar neurons in brain slices (Bacci et al., 2002; Tu et al., 2005; Giesbrecht et al., 2010).

Membrane voltages were adjusted for liquid junction potentials calculated using JPCalc software (P. Barry, University of New South Wales, Sydney, Australia; modified for Molecular Devices). Currents were filtered at $4-6 \mathrm{kHz}$ through a $-3 \mathrm{~dB}$, four-pole low-pass Bessel filter, digitally sampled at $20 \mathrm{kHz}$, and stored on a personal computer (ICT) using a commercially available data acquisition system (Digidata 1440A with pClamp 10.2 software; Molecular Devices).

\section{Histology and immunohistochemistry}

Brains were collected after perfusion with $4 \%$ paraformaldehyde for verification of cannula placement and immunohistochemistry. Brains were cut at $30 \mu \mathrm{m}$ on a sliding microtome through forebrain prefrontal re- gions, and the resulting sections were stored in cryoprotectant $(0.1 \mathrm{M}$ phosphate buffer, $30 \%$ sucrose, $1 \%$ polyvinylpyrrolidone, and $30 \%$ ethylene glycol) at $-20^{\circ} \mathrm{C}$ until processed for immunohistochemistry or histology. The following primary antibodies were used for doubleimmunofluorescence NPY (1:3000; Immunostar; Zhang et al., 2010), NPY receptor subtype $Y_{1}$ (1:50; Immunostar; Rostkowski et al., 2009), glutamic acid decarboxylase 67 (GAD67; 1:1000; Millipore), and calcium/calmodulin-dependent kinase II (CaMKII; 1:1000; Abcam). Sections were transferred from cryoprotectant to $50 \mathrm{~mm}$ potassium PBS (KPBS; pH 7.2; $40 \mathrm{~mm}$ potassium phosphate dibasic, $10 \mathrm{~mm}$ potassium phosphate monobasic, and $0.9 \%$ sodium chloride) at RT. Cryoprotectant was rinsed (five times for $5 \mathrm{~min}$ ) in KPBS, and the sections were transferred to KPBS plus $1.0 \% \mathrm{H}_{2} \mathrm{O}_{2}$ and incubated for $10 \mathrm{~min}$ at RT. Sections were then washed (five times for $5 \mathrm{~min}$ ) in KPBS at RT and placed in blocking solution [ $50 \mathrm{~mm}$ KPBS, $0.1 \%$ bovine serum albumin (BSA), and $0.2 \%$ Triton $\mathrm{X}-100$ ] for $1 \mathrm{~h}$ at RT. Sections were incubated overnight $\left(48 \mathrm{~h}\right.$ for $\left.\mathrm{Y}_{1}\right)$ at $4^{\circ} \mathrm{C}$ in primary antibody diluted in blocking solution. The following day, sections were rinsed in KPBS (five times for $5 \mathrm{~min}$ ) and incubated in biotinylated anti-rabbit (or anti-mouse) secondary antibody (Vector Laboratories) diluted 1:500 in KPBS plus $0.1 \%$ BSA for $1 \mathrm{~h}$ at RT. Sections were rinsed in KPBS (five times for $5 \mathrm{~min}$ ) and then treated with avidin-biotin complex (Vector Laboratories) at 1:1000 in KPBS plus $0.1 \%$ BSA for $1 \mathrm{~h}$ at RT. After this incubation, sections were rinsed again in KPBS (five times for $5 \mathrm{~min}$ ) and subsequently incubated in biotin-labeled tyramide (PerkinElmer Life and Analytical Sciences) at 1:250 in KPBS with $0.3 \% \mathrm{H}_{2} \mathrm{O}_{2}$ for $10 \mathrm{~min}$ at RT. Sections were rinsed in KPBS (five times for $5 \mathrm{~min}$ ) and incubated in $\mathrm{Cy} 3$-conjugated streptavidin (Jackson ImmunoResearch) diluted 1:500 for $1 \mathrm{~h}$ at RT on a shaker in the dark. For double labeling, sections were rinsed (five times for $5 \mathrm{~min}$ ) in KPBS and then incubated in the second primary antibody diluted as indicated in KPBS plus $0.1 \%$ BSA. After KPBS rinses (five times for 5 $\min )$, slices were then incubated in Cy5-labeled secondary antibody (Jackson ImmunoResearch) diluted 1:500 in KPBS plus 0.1\% BSA at RT for $1 \mathrm{~h}$ covered. Sections were rinsed five times for $5 \mathrm{~min}$ in KPBS at RT after the final antibody incubation, mounted onto Superfrost Plus slides, and coverslipped with Gelvatol.

Sections were imaged using an AxioImager Z1 microscope (Zeiss) equipped with apotome ( $Z$-stack) imaging capability (Axiocam MRm camera and AxioVision Release 4.6 software; Zeiss). All images were collected using a $20 \times$ air objective lens. Cy3 was excited using the 568 $\mathrm{nm}$, whereas $647 \mathrm{~nm}$ was used to collect images of Cy5-labeled cells. Colocalization was determined by overlapping signals. Images from the IL-PFC ( 3.2 to $2.20 \mathrm{~mm}$ from bregma) were acquired as $Z$-stacks. Flattened images were examined using NIH Image J software to quantify the total number of $\mathrm{Y}_{1}$-positive cells and the number colocalized with GAD67 or CaMKII using the cell counter tool. For immunohistochemistry data (Table 1), $n=5$ rats were used (three slices per animal). Brightness and contrast of the photomicrographs presented here were adjusted using Adobe Photoshop CS2 (Adobe Systems) to ensure the highestquality images for publication.

\section{Statistical analysis}

Histological assessment was performed on cresyl-stained sections, and animals were included in statistical analysis if injector tracts were clearly visible within the stereotaxic coordinates defining the IL cortex (reported $n$ for each group represents "hits"). Behavior scored manually by individuals blinded to treatment was used for analyses. Total seconds freezing during each tone presentation is expressed as a percentage of total tone presentation time. Data were analyzed using two-way repeated-measures ANOVAs (treatment $\times$ trial) or using one-way ANOVA or $t$ test (unpaired) when comparing mean percentage freezing for specific trial blocks between treatments (Prism 5; GraphPad Software). Repeatedmeasures ANOVA was used to analyze HPA response after restraint stress over blocks of time. Mean immobility counts in the FST test and error scores for the DSWS test for aCSF and NPY cohorts were analyzed using unpaired $t$ test. Post hoc comparisons were performed using the Holms-Sidak analysis.

Synaptic currents were analyzed using Clampfit (Molecular Devices) software, and mean current amplitudes were calculated using 1 min bins. 
Data are expressed as means \pm SEMs. Normalized current amplitudes were compared between NPY and control (aCSF) conditions using twoway ANOVA. $n$ refers to the number of neurons sampled in a given group unless specified otherwise. Prism software was used to analyze all data (GraphPad Software).

\section{Results \\ IL NPY infusion compromises extinction consolidation leading to impaired retrieval of extinction memory}

To evaluate the role of NPY on extinction acquisition and memory, we infused NPY into the IL subdivision of the mPFC $30 \mathrm{~min}$ before extinction training on Day 2 (Fig. 1C). This timing of intervention was chosen to evaluate NPY effects on fear expression, extinction learning, and memory. An NPY dose-response study showed no effects of NPY on Day 2 fear expression and extinction training as indicated by similar levels of freezing between NPY and aCSF groups (Fig. 1D). There was a significant effect of trial block $\left(F_{(9,247)}=18.93 ; p<0.05\right)$ but no effect of treatment $\left(F_{(3,247)}=0.65 ; p>0.05\right)$. However, a significant impairment of extinction memory retrieval was observed on Day 3 in rats infused with 10 and 30 pmol NPY but not at the 3 pmol dose (Fig. $1 D$, right). Repeated-measures ANOVA revealed a main effect of treatment $\left(F_{(3,255)}=12.83 ; p<0.05\right)$, trial $\left(F_{(9,225)}\right.$ $=20.99 ; p<0.05)$, and a significant trial $\times$ treatment interaction $\left(F_{(27,255)}=1.833 ; p<0.05\right)$. Post hoc comparisons confirmed that 10 and 30 pmol NPY-infused rats showed significantly higher levels of freezing during trial blocks $2-4(p<0.05)$ but no significant effects at 3 pmol NPY.

To confirm that NPY effects on retrieval were attributable to impaired consolidation of extinction and not a state-dependent phenomenon, we infused NPY (10 pmol) immediately after extinction training (Fig. 1E). Post-extinction NPY infusion also resulted in significantly higher freezing during extinction retrieval compared with aCSF-infused rats (Fig. $1 F$ ). Repeatedmeasures ANOVA revealed a significant effect of treatment $\left(F_{(1,10)}=16.04 ; p<0.05\right)$, trial block $\left(F_{(9,80)}=13.37 ; p<0.05\right)$, and a trend in trial $\times$ treatment interaction $\left(F_{(9,80)}=1.917 ; p=\right.$ 0.068 ), confirming that NPY compromises the consolidation of extinction.

\section{NPY effects on extinction memory retrieval are mediated via the NPY $\mathrm{Y}_{1} \mathrm{R}$}

Selective $\mathrm{Y}_{1} \mathrm{R}$ antagonist $\mathrm{BIBO}$ was infused $10 \mathrm{~min}$ before NPY (10 pmol) administration on Day 2 (Fig. 2A). To investigate the role of tonic endogenous NPY on extinction memory, a separate cohort of rats was infused with BIBO alone without NPY. No significant differences in freezing were noted between groups during acquisition of extinction (Fig. 2B). Freezing was significantly attenuated during retrieval of extinction in NPY rats treated with BIBO (Fig. $2 B$ ). Two-way ANOVA revealed a significant main effect of treatment $\left(F_{(3,297)}=9.18 ; p<0.05\right)$ and trial $\left(F_{(9,297)}=26.72 ; p<0.05\right)$. BIBO-treated NPY rats showed equivalent levels of freezing as the control aCSF group $\left(F_{(1,198)}=\right.$ $0.81 ; p>0.05)$, suggesting that $\mathrm{Y}_{1} \mathrm{R}$ antagonism was sufficient to block the effects of NPY on extinction memory. Interestingly, animals treated with BIBO in the absence of NPY showed no significant difference in freezing compared with aCSF-treated animals $\left(F_{(1,164)}=0.51 ; p>0.05\right)$. As shown in Figure $2 C$, mean freezing in the NPY-treated group during initial trial blocks 1-4 was higher than control, BIBO alone, and BIBO plus NPY groups (one-way ANOVA; $F=3.544 ; p<0.05$ ). Post hoc analysis revealed significant differences between NPY and other treatment groups $(p<0.05)$.
NPY infusion into the IL cortex does not regulate neuroendocrine stress responses, depression-like behavior, or working memory performance

No significant differences were observed between NPY- and aCSF-infused animals in corticosterone response after restraint stress at any time interval (Fig. 3A). Two-way repeated-measures ANOVA revealed a significant effect of time $\left(F_{(3,54)}=85.82 ; p<\right.$ $0.05)$, with no effect of treatment $\left(F_{(1,54)}=0.09 ; p>0.05\right)$. There was no significant difference between immobility scores of aCSFand NPY-treated animals in the FST (Fig. $3 B ; t=0.8663 ; p>0.05$ by $t$ test). Additionally, NPY IL infusion did not elicit any significant effects on across-phase errors $(t=0.8356$; $p>0.05)$ or within-phase errors $(t=0.3254 ; p>0.05)$ during the retrieval phase of DSWS testing in the RAM (Fig. $3 C, D$ ).

\section{NPY enhances synaptic inhibition onto IL-PFC pyramidal neurons}

To examine the effects of NPY on inhibitory and excitatory synaptic signaling within the IL-PFC, GABA ${ }_{\mathrm{A}} \mathrm{R}$-mediated IPSCs (Fig. 4A) or AMPAR-mediated EPSCs (Fig. 4C) were evoked in layer $\mathrm{V}$ pyramidal neurons via electrical stimulation in layers II-III. NPY $(1 \mu \mathrm{M})$ led to a marked potentiation of IPSCs (Fig. $4 A$ ) that outlasted the duration of the NPY exposure itself $(n=$ $11 ; p<0.0001$ compared with aCSF only; two-way ANOVA; Fig. $4 B)$. No such increase in IPSC amplitude was observed in layer $\mathrm{V}$ pyramidal neurons during continued perfusion with aCSF $(n=5$; Fig. $4 B)$. In contrast, the bath application of NPY $(1 \mu \mathrm{M})$ evoked a modest, but statistically significant, decrease in EPSC amplitude $(n=12 ; p=0.028$ compared with aCSF only; two-way ANOVA; Fig. 4D). Control experiments involving aCSF perfusion revealed no consistent time-dependent changes in EPSC amplitude during the $20-25$ min recording period ( $n=5$; Fig. $4 D$ ). Collectively, the results suggest that NPY significantly shifts the functional balance between synaptic excitation and inhibition onto layer $\mathrm{V}$ pyramidal neurons in a manner that would be predicted to reduce action potential discharge in the output neurons of the IL-PFC.

\section{Expression of NPY and NPY $Y_{1} R$ on IL neurons}

As shown in Figure 5, the $\mathrm{Y}_{1} \mathrm{R}$ was predominantly expressed on cell soma with negligible fiber staining. $\mathrm{Y}_{1} \mathrm{R}$ expression was evident in excitatory pyramidal cells positive for CaMKII, a marker for projection neurons (Rostkowski et al., 2009; Fig. 5A-C). CaMKII colabeled cells accounted for $\sim 60.5 \%$ of $Y_{1} R$-expressing cells (Table 1). $\mathrm{Y}_{1}$ expression was also observed in a few scattered cells positive for GAD67, a marker for GABAergic interneurons (Fig. 5D-F). GAD67 colabeled cells represented $\sim 12.7 \%$ of $\mathrm{Y}_{1} \mathrm{R}$ expressing cells (Table 1). We also observed a few NPYimmunopositive cell soma that were positive for GAD67 (Fig. $5 G-I)$. No colocalization was observed between NPY- and CaMKII-positive cells (data not shown).

\section{Discussion}

Using behavioral, electrophysiological, and immunohistochemical approaches, we found the following: (1) pre-extinction and postextinction training infusion of NPY in the IL cortex impaired retrieval of extinction memory, leaving the acquisition of extinction intact; (2) this effect was mediated via the $Y_{1} R$, the predominant NPY receptor subtype in cortical areas; (3) NPY application increased inhibitory synaptic transmission onto IL projection neurons; (4) neuroendocrine stress response, depression-like behavior, and working memory performance were not affected by IL NPY; and (5) in the IL cortex, NPY and $Y_{1}$ receptors are expressed in inhibitory 


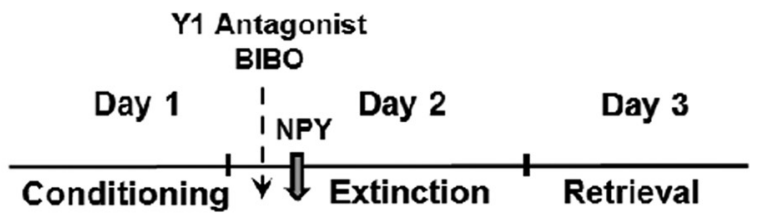

B
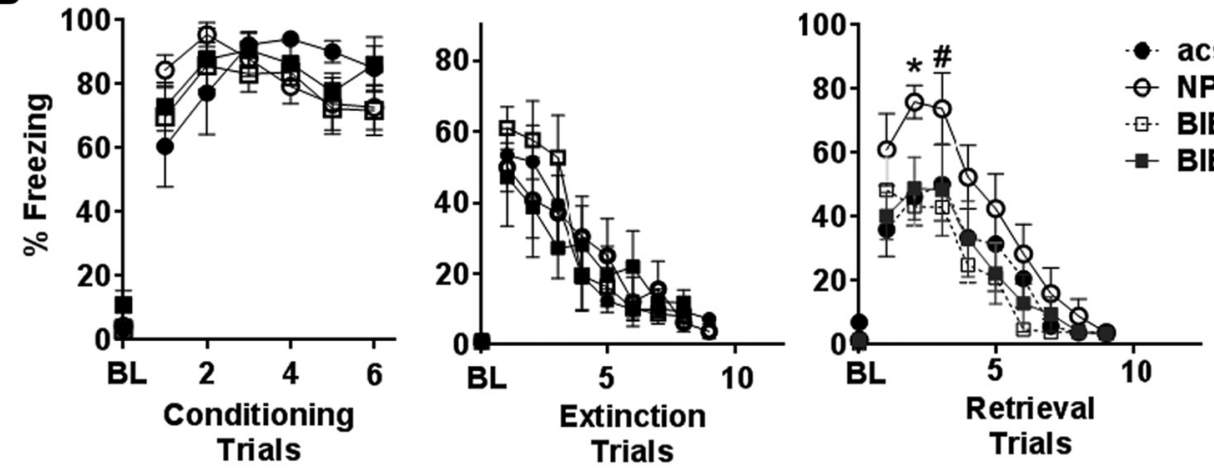

C

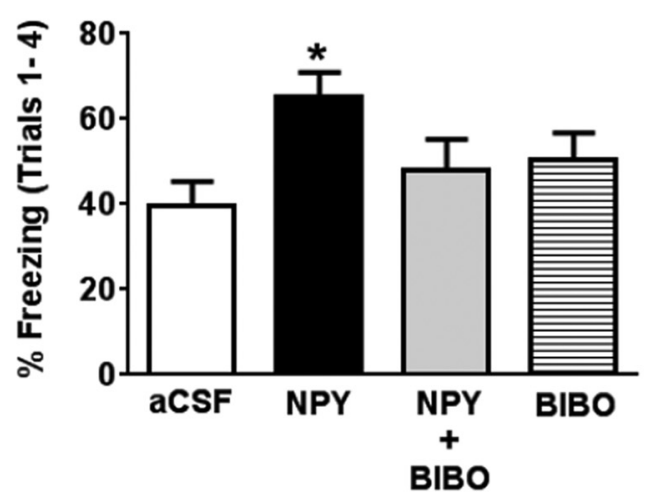

Figure 2. $N P Y Y_{1} R$ subtype mediates effects of $N P Y$ on extinction memory. $A$, Timeline of experiment. $Y_{1} R$ antagonist $B I B O$ was infused 10 min before NPY infusion 30 min before extinction training on Day 2. B, Freezing response of rats infused with aCSF $(n=7), \mathrm{NPY}(10 \mathrm{pmol} ; n=9), \mathrm{BIBO}(200 \mathrm{pmol} ; n=8)$, and BIBO and NPY (BIBO-NPY; $n=10)$. NPY-evoked impairment of extinction retrieval (increased freezing; right) was attenuated significantly in rats infused with BIBO to levels observed in the aCSF treatment group. Rats infused with BIBO by itself did not elicit any significant differences in freezing during retrieval of extinction compared with aCSF cohort. No significant differences in conditioning (left) or conditioned fear expression and extinction learning (middle) were observed between groups. C, Mean percentage freezing during trials 1-4 showed significantly increased freezing in the NPY treatment group compared with aCSF, BIBO-NPY, and BIBO-alone groups. Data shown are mean \pm SEM. ${ }^{*} p<0.05$ versus other groups; ${ }^{p} p<0.05$ versus the BIBO-NPY group. For conditioning, data on post-shock freezing for shocks $1-6$ is shown. For extinction and retrieval, data from tones $1-9$ is shown. Magnitude of freezing plateaued at these time points, and no additional changes in freezing were observed for subsequent trials. BL represents baseline freezing during 2 min before the delivery of conditioning, extinction, or retrieval trials.

GABAergic neurons and excitatory pyramidal projection neurons, placing them in an optimal position for regulating excitatory/inhibitory neurotransmission.

Infusion of NPY in the IL cortex before and immediately after extinction training elicited a robust impairment of extinction retrieval via inhibition of extinction consolidation, suggesting inactivation of this region by NPY. This is not surprising given that NPY is an inhibitory neuropeptide with potent antiexcitatory actions in other brain regions, such as the hippocampus, amygdala, and neocortex (Bacci et al., 2002; Colmers and Bleakman, 1994; Giesbrecht et al., 2010; Molosh et al., 2013). Effects of NPY on extinction memory were mediated by the NPY $\mathrm{Y}_{1} \mathrm{R}$ subtype, which is abundantly expressed on projection neurons of the IL cortex (Fig. 5) and modulates NPY regulation of fear extinction in the amygdala (Gutman et al., 2008). Retrieval of extinction is an IL-mediated outcome, because inactivation by IL-directed lesions or infusion of muscimol or TTX (Quirk and Mueller, 2008; Sierra-Mercado et al., 2011) compromises retrieval. Neuronal activity in the IL cortex during extinction affects the consolidation of extinction learning (Burgos-Robles et al.,
2007) and appears critical for the expression of extinction memory. Optogenetic silencing of IL neurons during extinction had no effects on within-session extinction but impaired recall after $24 \mathrm{~h}$ (Do-Monte et al., 2015), suggesting a recruitment of the IL cortex during extinction training. Similarly, our data imply that NPY-evoked inhibition of IL activity during training and consolidation phases of extinction lead to impaired retrieval.

IL glutamatergic networks are critically involved in plasticity during extinction learning (Sotres-Bayon et al., 2004; Burgos-Robles et al., 2007). AMPAR/NMDAR activation during extinction training and consolidation is required for successful extinction retrieval after 24 h (Burgos-Robles et al., 2007; Sotres-Bayon et al., 2009). Meanwhile, enhancement of inhibitory GABAergic neurotransmission (e.g., by muscimol) infused before acquisition of extinction (but not before retrieval) impairs retrieval of extinction memory (SierraMercado et al., 2011; Do-Monte et al., 2015).

Given the relevance of inhibitory and excitatory neurotransmission in extinction memory, we investigated whether NPY could modulate excitatory/inhibitory signaling in IL neurons. Our electrophysiological results suggest a potent inhibitory effect 
A

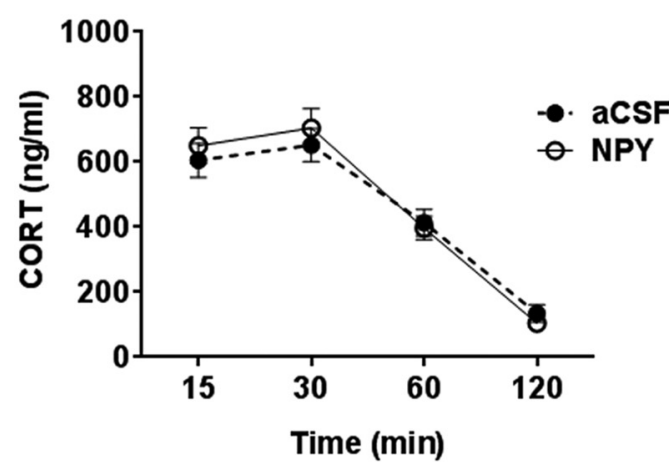

C

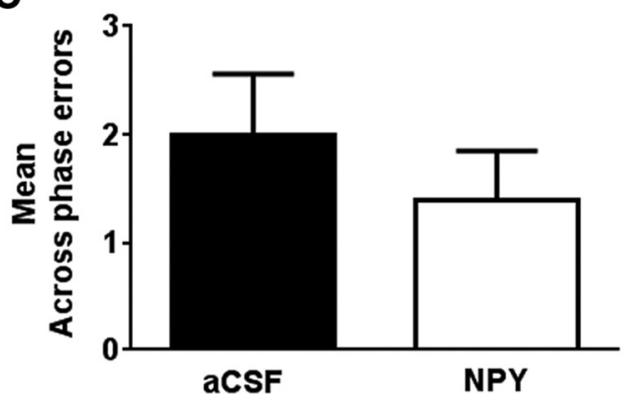

B

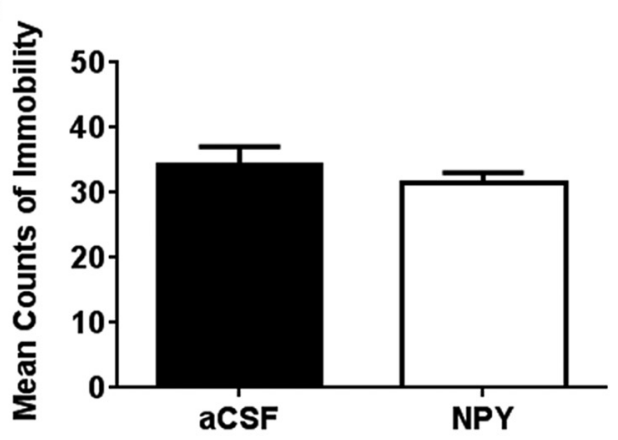

D

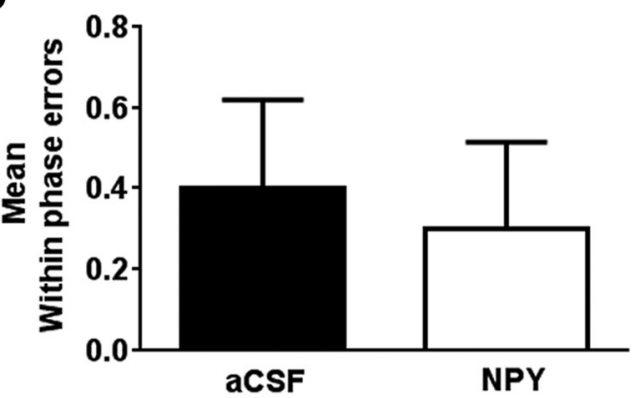

Figure 3. Infusion of NPY into the IL cortex does not affect postrestraint neuroendocrine stress response, depression-like behavior in the FST, or working memory performance in the RAM. $\boldsymbol{A}$, HPA response to restraint stress. Blood was collected from the tail vein at 15, 30,60, and 120 min from the time the animals were exposed to the stressor (aCSF, $n=10 ; \mathrm{NPY}, n=9)$. $\boldsymbol{B}, \mathrm{FST}$ behavior test. Immobility scores over 5 min for aCSF-infused $(n=12)$ and NPY-infused $(n=11)$ rats in the FST. Scores during the initial 5 min are reported because of high immobility in both groups after this period. $\boldsymbol{C}, \boldsymbol{D}$, RAM memory test. Mean across-phase $(\boldsymbol{C}$ ) and within-phase $(\boldsymbol{D})$ errors during retrieval testing are reported ( $n=10$ per group). No significant difference was noted between the NPYand aCSF-infused animals in HPA response, immobility in the FST, or mean across-phase errors or within-phase errors in the RAM test compared with aCSF-infused rats. Data are mean \pm SEM $(p>0.05)$.

A

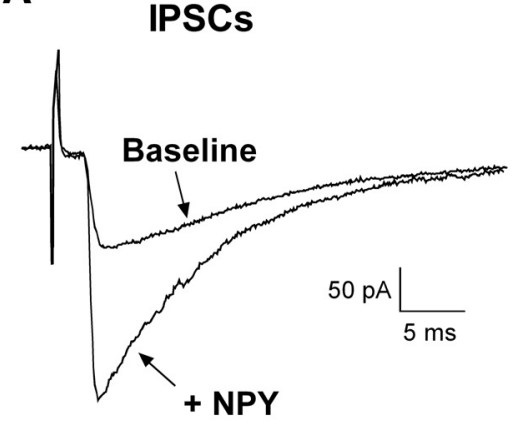

C

EPSCs

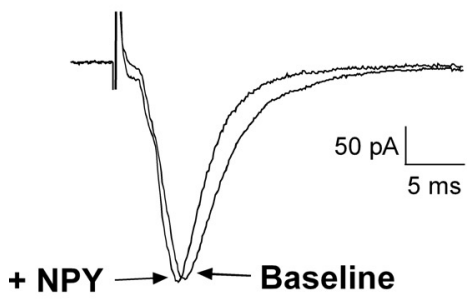

B

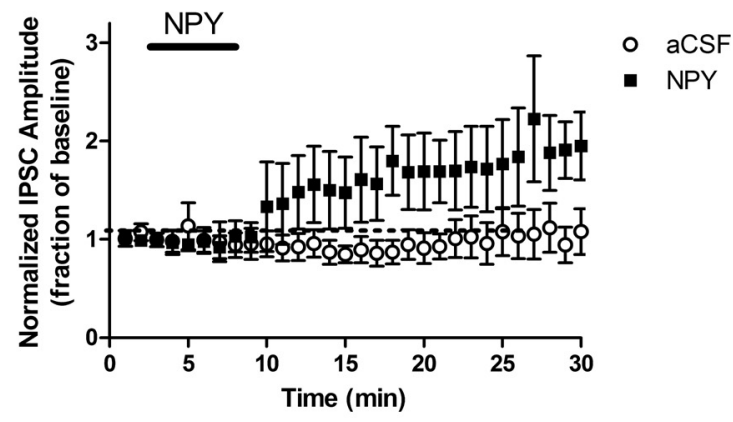

D

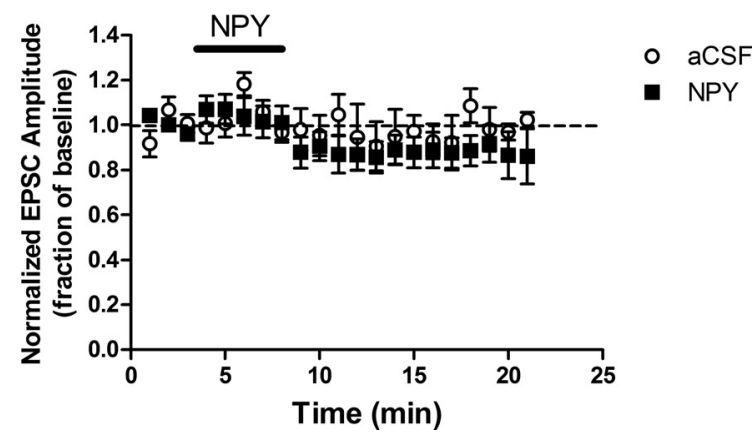

Figure 4. NPY potentiates GABAergic inhibition onto layer V pyramidal neurons in the IL-PFC. A, Examples of IPSC in a layer VIL-PFC neuron after focal electrical stimulation in layers II-III, before (Baseline) and after the administration of NPY (1 $\mu$ M). B, NPY significantly enhanced IPSC amplitude in these neurons (aCSF, $n=5 ; \mathrm{NPY}, n=11 ; p<0.0001$; two-way ANOVA). C, Representative examples of AMPAR-mediated EPSCs in a layer V neuron either before (Baseline) or after bath application of NPY (1 $\mu \mathrm{M})$. D, Plot of normalized EPSC amplitude as a function of time demonstrating a slight but significant reduction in EPSC amplitudes after NPY exposure $(n=12 ; p=0.028$; two-way ANOVA) compared with control conditions (i.e., continued perfusion with aCSF; $n=5)$. 

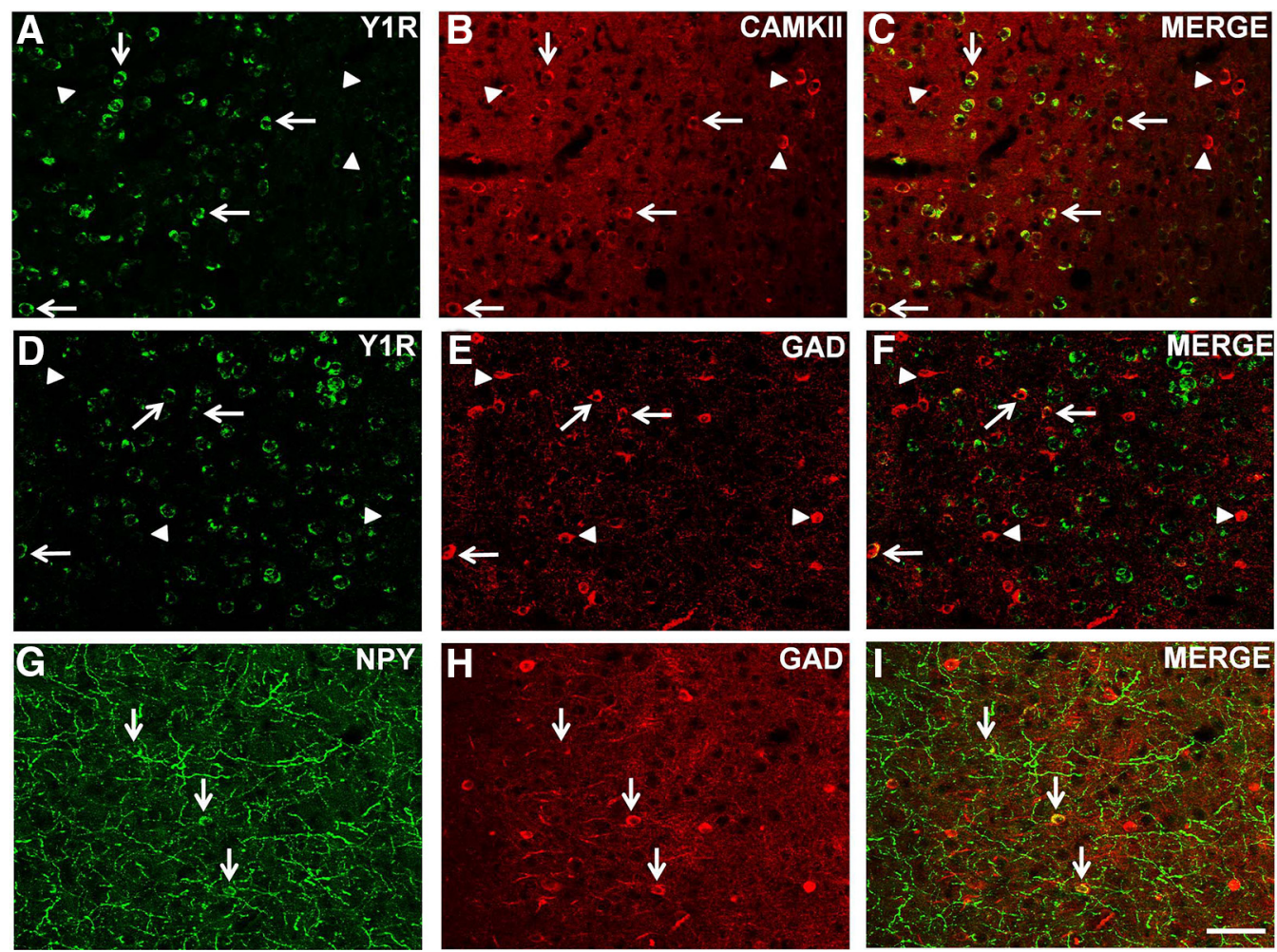

Figure 5. Colocalization of $Y_{1} R(\boldsymbol{A}-\boldsymbol{F})$ and NPY $(\boldsymbol{G}-\boldsymbol{I})$ with CaMKII-IR or GAD67-IR cells in the IL cortex. $Y_{1} R$-immunopositive cells $(\boldsymbol{A})$ showed colocalization with CaMKII-IR cells $(\boldsymbol{B})$ as seen in merged image ( $\boldsymbol{C}$. A few $Y_{1} R$-positive cells also colocalized with GAD67-IR cells $(\boldsymbol{E})$ as seen in merged image $(\boldsymbol{F})$. NPY-IR cells $(\boldsymbol{G})$ showed colocalization with GAD67-IR cells $(\boldsymbol{H}$; see $\boldsymbol{I}$ for merged image). Double-labeled cells (arrows) and single-labeled CaMKII or GAD67 cells (arrowheads) are visible. Scale bar, $20 \mu \mathrm{m}$.

Table 1. Distribution of $\mathrm{Y}_{1} \mathrm{R}$ immunoreactivity on CaMKII-positive glutamatergic and GAD67-positive GABAergic neurons in the rat IL cortex (see Fig 5)

\begin{tabular}{lcl}
\hline Population $\mathrm{Y}_{1} R$ cells & Double-labeled population & \% Double-labeled \\
\hline $403 \pm 34$ & $248 \pm 28$ (CaMKII positive) & 60.5 (GaMKII) \\
$523 \pm 19$ & $65 \pm 6$ (GAD67positive) & 12.7 (GAD67) \\
\hline
\end{tabular}

Data shown are mean \pm SEM $(n=5 ; 3$ slices per animal).

of NPY on the excitability of layer V pyramidal neurons, as evidenced by a persistent increase in $\mathrm{GABA}_{\mathrm{A}} \mathrm{R}$-mediated IPSCs and a modest decrease in evoked AMPAR-mediated EPSCs, which agrees with previous observations in neocortical, BLA, and hippocampal pyramidal neurons (McQuiston and Colmers, 1996; Bacci et al., 2002; Molosh et al., 2013). NPY is expressed in GADpositive GABA interneurons (Fig. 5) and can regulate GABA release (Sun et al., 2003). Although additional investigation is required to identify the underlying mechanisms, these NPYevoked changes in synaptic efficacy are predicted to decrease excitability in cortical circuits, leading to dampened IL output and an impairment of extinction retrieval.

Output from the IL cortex suppresses the freezing response to tone via projections to the intercalated cells of the BLA, which, in turn, regulate central amygdala control of freezing (Quirk and $\mathrm{Mu}$ eller, 2008). Because $Y_{1} R$ antagonism completely blocked effects of NPY on extinction retrieval, it is likely that activation of the $Y_{1} R$ by NPY reduces the activation of these neurons during extinction learning and consolidation, thereby affecting extinction memory. Our immunohistochemical studies revealed $Y_{1} R$ expression on a subset of CaMKII-positive pyramidal projection neurons and GAD67positive interneurons in the IL cortex. We also found that NPY expression was localized to inhibitory GAD67-positive interneurons as reported previously (Eriksdotter-Nilsson et al., 1987; Alho et al.,
1988). Collectively, observed antagonism of NPY effects on fear by $Y_{1} R$ antagonist, expression of $Y_{1} R$ and NPY on pyramidal projection neurons, and modulation of synaptic transmission onto pyramidal neurons by NPY suggest that NPY and the $Y_{1} R$ are optimally positioned for controlling excitatory output from prefrontal circuits and regulating retrieval of extinction.

In addition to fear memory modulation, the mPFC plays an important role in regulating neuroendocrine and behavioral responses to psychogenic stressors and in cognitive performance (Figueiredo et al., 2002; Spencer et al., 2005; Radley et al., 2006; Wulsin et al., 2010; Caetano et al., 2012). Recent studies report modulation of forced swim behavior and HPA activity by IL-specific knockdown of glucocorticoid receptors (McKlveen et al., 2013). Specific lesions to the IL cortex result in inhibition of HPA response to acute restraint stress, suggesting that this region activates HPA output (Radley et al., 2006). No effects of NPY infusion on post-restraint HPA response/ recovery, immobility in the FST, and working memory retrieval errors suggest that increased IL NPY does not have generalized effects on stress response, depression-like behaviors, or cognitive tasks under our test conditions.

\section{Pathophysiological implications}

Modulation of extinction memory by prefrontal NPY has important pathophysiological implications. Reduced activation in the vmPFC has been reported in PTSD subjects in association with impaired extinction recall (Milad et al., 2009). Increased prefrontal NPY may compromise top-down regulation of regions such as the amygdala and result in impaired processing of fear memories, leading to increased vulnerability to anxiety disorders such as PTSD.

Our data contrasts with previous studies reporting attenuation of conditioned fear and facilitated extinction by NPY (Gut- 
man et al., 2008; Verma et al., 2012; Lach and de Lima, 2013). Global NPY and NPY receptor knock-out mice exhibit enhanced fear acquisition and conditioned fear, as well as impaired extinction (Verma et al., 2012). Because infusion of the $Y_{1}$ antagonist alone did not have any behavioral effects in our study, the prefrontal NPY system may not be recruited under tonic conditions tested in these studies. However, increased cortical NPY occurring as a result of NPY genetic polymorphisms (Sommer et al., 2010), or after exposure to chronic stress (McGuire et al., 2011), may lead to increased synaptic concentrations of NPY. Intracerebroventricular infusion of NPY attenuated conditioned fear and improved extinction, an effect mediated by $\mathrm{Y}_{1} \mathrm{Rs}$ in the BLA (Gutman et al. 2008, Fendt et al. 2009). Retrieval of extinction memory, a phenomenon regulated by the IL cortex, has not been investigated previously. Our results in conjunction with previous work suggest that fear regulatory effects of NPY are complex and depend on the modulation of excitatory/inhibitory tone by NPY in distinct fear circuits. Thus, NPY-mediated inhibition of BLA projection neurons (Giesbrecht et al., 2010; Molosh et al., 2013) would reduce fear and improve extinction (Gutman et al., 2008), whereas NPY-mediated inhibition of IL projection neurons would compromise IL-mediated excitation of intercalated (ITC) GABAergic neurons and enhance fear. Regional disparity between PFC and amygdala NPY expression is supported by previous observations. In a rodent model of chronic traumatizationevoked sensitization of fear, differential effects on NPY expression are observed: low in the amygdala and high in PFC (McGuire et al., 2011). In this regard, NPY gene polymorphism rs14167 is associated with differential NPY mRNA expression in the brain: high in the PFC (Sommer et al., 2010) versus low in other brain regions (Zhou et al., 2008). Differences in posttranscriptional processing, synthesis, degradation, or transport may result in these effects. Importantly, both decreased amygdala NPY and increased PFC NPY will lead to compromised processing of fear memories.

Previous work has proposed a role of NPY in PTSD, albeit as a stress resiliency factor (Wu et al., 2011; Sah and Geracioti, 2013). Reduced CSF concentration of NPY is observed in combat-related PTSD subjects (Sah et al., 2009, 2014). Currently, information on regional concentrations of NPY in postmortem brain samples from PTSD subjects is lacking. Thus, it is not evident whether lower CSF NPY reflects a global reduction. Dynamics of NPY diffusion into the CSF compartment is not known but may contribute to regional differences. Our data also have implications for NPY therapeutics, especially with regard to fear memory regulation. NPY supplementation via intranasal route or hippocampal infusion is beneficial for stress-, anxiety-, and startle-related outcomes in rodent models (Cohen et al., 2012; Serova et al., 2013). It would be important to investigate IL NPY and extinction memory outcomes in these models. Regional disparities in NPY expression/function should be considered as therapeutic options for NPY to become available in humans. Although the current study focused on male rats, it will be of interest to investigate sex differences given the vulnerability of females to fear processing disorders such as PTSD (Inslicht et al., 2013).

In conclusion, we report modulation of IL neuronal excitation and extinction memory by NPY. In individuals expressing rs14167 gene polymorphism or with a history of chronic stress exposure, elevated prefrontal NPY may contribute to IL hypoactivity, resulting in impaired extinction memory and increased susceptibility to anxiety disorders such as PTSD.

\section{References}

Adrian TE, Allen JM, Bloom SR, Ghatei MA, Rossor MN, Roberts GW, Crow TJ, Tatemoto K, Polak JM (1983) Neuropeptide Y distribution in human brain. Nature 306:584-586. CrossRef Medline

Alho H, Ferrarese C, Vicini S, Vaccarino F (1988) Subsets of GABAergic neurons in dissociated cell cultures of neonatal rat cerebral cortex show co-localization with specific modulator peptides. Brain Res 467:193-204. Medline

Allen YS, Adrian TE, Allen JM, Tatemoto K, Crow TJ, Bloom SR, Polak JM (1983) Neuropeptide Y distribution in rat brain. Science 221:877-879. CrossRef Medline

Bacci A, Huguenard JR, Prince DA (2002) Differential modulation of synaptic transmission by neuropeptide $\mathrm{Y}$ in rat neocortical neurons. Proc Natl Acad Sci U S A 99:17125-17130. CrossRef Medline

Burgos-Robles A, Vidal-Gonzalez I, Santini E, Quirk GJ (2007) Consolidation of fear extinction requires NMDA receptor-dependent bursting in the ventromedial prefrontal cortex. Neuron 53:871-880. CrossRef Medline

Butts KA, Weinberg J, Young AH, Phillips AG (2011) Glucocorticoid receptors in the prefrontal cortex regulate stress-evoked dopamine efflux and aspects of executive function. Proc Natl Acad Sci U S A 108:18459-18464. CrossRef Medline

Caetano MS, Jin LE, Harenberg L, Stachenfeld KL, Arnsten AF, Laubach M (2012) Noradrenergic control of error perseveration in medial prefrontal cortex. Front Integr Neurosci 6:125. CrossRef Medline

Cohen H, Liu T, Kozlovsky N, Kaplan Z, Zohar J, Mathé AA (2012) The neuropeptide Y (NPY)-ergic system is associated with behavioral resilence to stress exposure in an animal model of post-traumatic stress disorder. Neuropsychopharmacology 37:350-363. CrossRef Medline

Colmers WF, Bleakman D (1994) Effects of neuropeptide Y on the electrical properties of neurons. Trends Neurosci 17:373-379. CrossRef Medline

Do-Monte FH, Manzano-Nieves G, Quiñones-Laracuente K, Ramos-Medina L, Quirk GJ (2015) Revisiting the role of the infralimbic cortex in fear extinction with optogenetics. J Neurosci 35:3607-3615. CrossRef Medline

Dumont Y, Fournier A, St-Pierre S, Quirion R (1996) Autoradiographic distribution of $\left.\left[{ }^{125} \mathrm{I}\right] \mathrm{Leu}_{31}, \mathrm{Pro}_{34}\right] \mathrm{PYY}$ and $\left[{ }^{125} \mathrm{I}\right] \mathrm{PYY}_{3-36}$ binding sites in the rat brain evaluated with two newly developed Y1 and Y2 receptor radioligands. Synapse 22:139-158. CrossRef Medline

Eaton K, Sallee FR, Sah R (2007) Relevance of neuropeptide Y (NPY) in psychiatry. Curr Top Med Chem 7:1645-1659. CrossRef Medline

Eriksdotter-Nilsson M, Meister B, Hökfelt T, Elde R, Fahrenkrug J, Frey P, Oertel W, Rehfeld JF, Terenius L, Olson L (1987) Glutamic acid decarboxylase- and peptide-immunoreactive neurons in cortex cerebri following development in isolation: evidence of homotypic and disturbed patterns in intraocular grafts. Synapse 1:539-551. CrossRef Medline

Fendt M, Bürki H, Imobersteg S, Lingenhöhl K, McAllister KH, Orain D, Uzunov DP, Chaperon F (2009) Fear reducing effects of inta-amygdala neuropeptide $Y$ infusion in animal model of conditioned fear: an NPY Y1 receptor independent effect. Psychopharmacology 206:291-301. CrossRef Medline

Figueiredo HF, Dolgas CM, Herman JP (2002) Stress activation of cortex and hippocampus is modulated by sex and stage of estrus. Endocrinology 143:2534-2540. CrossRef Medline

Floresco SB, Seamans JK, Phillips AG (1997) Selective roles for hippocampal, prefrontal cortical and ventral striatal circuits in radial-arm maze tasks with or without a delay. J Neurosci 17:1880-1890. Medline

Giesbrecht CJ, Mackay JP, Silveira HB, Urban JH, Colmers WF (2010) Countervailing modulation of Ih by neuropeptide $\mathrm{Y}$ and corticotrophinreleasing factor in basolateral amygdala as a possible mechanism for their effects on stress-related behaviors. J Neurosci 30:16970-16982. CrossRef Medline

Gutman AR, Yang Y, Ressler KJ, Davis M (2008) The role of Neuropeptide Y in the expression and extinction of fear-potentiated startle. J Neurosci 28:12682-12690. CrossRef Medline

Heilig M, Widerlöv E (1995) Neurobiology and clinical aspects of neuropeptide Y. Crit Rev Neurobiol 9:115-136. Medline

Inslicht SS, Metzler TJ, Garcia NM, Pineles SL, Milad MR, Orr SP, Marmar CR, Neylan TC (2013) Sex differences in fear conditioning in posttraumatic stress disorder. J Psychiatr Res 47:64-71. CrossRef Medline

Jovanovic T, Norrholm SD, Blanding NQ, Davis M, Duncan E, Bradley B, Ressler KJ (2010) Impaired fear inhibition is a biomarker of PTSD but not depression. Depress Anxiety 27:244-251. CrossRef Medline

Lach G, de Lima TC (2013) Role of NPY Y1 receptor on acquisition, consolidation, and extinction on contextual fear conditioning: dissociation 
between anxiety, locomotion and non-emotional memory. Neurobiol Learn Mem 103:26-33. CrossRef Medline

McGuire J, Herman JP, Horn PS, Sallee FR, Sah R (2010) Enhanced fear recall and emotional arousal in rats recovering from chronic variable stress. Physiol Behav 101:474-482. CrossRef Medline

McGuire JL, Larke LE, Sallee FR, Herman JP, Sah R (2011) Differential regulation of neuropeptide $\mathrm{Y}$ in the amygdala and prefrontal cortex during recovery from chronic variable stress. Front Behav Neurosci 5:54. CrossRef Medline

McKlveen JM, Myers B, Flak JN, Bundzikova J, Solomon MB, Seroogy KB, Herman JP (2013) Role of prefrontal cortex glucocorticoid receptors in stress and emotion. Biol Psychiatry 74:672-679. CrossRef Medline

McNally RJ (2006) Cognitive abnormalities in post-traumatic stress disorder. Trends Cog Sci 10:271-277. CrossRef Medline

McQuiston AR, Colmers WF (1996) Neuropeptide Y2 receptors inhibit the frequency of spontaneous but not miniature EPSCs in CA3 pyramidal cells of rat hippocampus. J Neurophysiol 76:3159-3168. Medline

Milad MR, Quirk GJ (2002) Neurons in medial prefrontal cortex signal memory for fear extinction. Nature 420:70-74. CrossRef Medline

Milad MR, Pitman RK, Ellis CB, Gold AL, Shin LM, Lasko NB, Zeidan MA, Handwerger K, Orr SP, Rauch SL (2009) Neurobiological basis of failure to recall extinction memory in posttraumatic stress disorder. Biol Psychiatry 66:1075-1082. CrossRef Medline

Molosh AI, Sajdyk TJ, Truitt WA, Zhu W, Oxford GS, Shekhar A (2013) NPY Y(1) receptors differentially modulate GABA(A) and NMDA receptors via divergent signal-transduction pathways to reduce excitability of amygdala neurons. Neuropsychopharmacology 38:1352-1364. CrossRef Medline

Parsons RG, Ressler KJ (2013) Implications of memory modulation for post-traumatic stress and fear disorders. Nat Neurosci 16:146-153. CrossRef Medline

Paxinos G, Watson C (1998) The rat brain in stereotaxic coordinates. San Diego: Academic.

Quirk GJ, Mueller D (2008) Neural mechanisms of extinction learning and retrieval. Neuropsychopharmacology 33:56-72. CrossRef Medline

Radley JJ, Arias CM, Sawchenko PE (2006) Regional differentiation of the medial prefrontal cortex in regulating adaptive responses to acute emotional stress. J Neurosci 26:12967-12976. CrossRef Medline

Rostkowski AB, Teppen TL, Peterson DA, Urban JH (2009) Cell-specific expression of neuropeptide Y Y1 receptor immunoreactivity in the rat basolateral amygdala. J Comp Neurol 517:166-176. CrossRef Medline

Sah R, Geracioti TD (2013) Neuropeptide Y and posttraumatic stress disorder. Mol Psychiatry 18:646-655. CrossRef Medline

Sah R, Ekhator NN, Strawn JR, Sallee FR, Baker DG, Horn PS, Geracioti TD Jr (2009) Low cerebrospinal fluid neuropeptide $Y$ concentrations in posttraumatic stress disorder. Biol Psychiatry 66:705-707. CrossRef Medline

Sah R, Ekhator N, Jefferson-Wilson L, Horn P, Geracioti T Jr (2014) Cerebrospinal fluid neuropeptide $\mathrm{Y}$ in combat veterans with and without posttraumatic stress disorder. Psychoneuroendocrinology 40:277-283. CrossRef Medline

Sajdyk TJ, Johnson PL, Leitermann R, Fitz SD, Dietrich A, Morin M, Gehlert DR, Urban JH, Shekhar A (2008) Neuropeptide Y in the amygdala induces long term resilience to stress-induced reductions in social responses but not hypothalamic-adrenal-pituitary axis activity or hyperthermia. J Neurosci 28:893-903. CrossRef Medline

Serova LI, TiLlinger A, Alaluf LG, Laukova M, Keegan K, Sabban EL (2013)
Single intranasal neuropeptide Y infusion attenuates development of PTSD-like symptoms to traumatic stress in rats. Neuroscience 236:298312. CrossRef Medline

Sierra-Mercado D, Padilla-Coreano N, Quirk GJ (2011) Dissociable roles of prelimbic and infralimbic cortices, ventral hippocampus, and basolateral amygdala in the expression and extinction of conditioned fear. Neuropsychopharmacology 36:529-538. CrossRef Medline

Sommer WH, Lidstrom J, Sun H, Passer D, Eskay R, Parker SC, et al, (2010) Human NPY promoter variation rs16147:T $>C$ as a moderator of prefrontal NPY gene expression and negative effect. Hum Mutation 31: E1594-E1608. CrossRef Medline

Sotres-Bayon F, Bush DE, LeDoux JE (2004) Emotional perseveration: an update on prefrontal-amygdala interactions in fear extinction. Learn Mem 11:525-535. CrossRef Medline

Sotres-Bayon F, Diaz-Mataix L, Bush DE, LeDoux JE (2009) Dissociable roles for the ventromedial prefrontal cortex and amygdala in fear extinction: NR2B contribution. Cereb Cortex 19:474-482. CrossRef Medline

Spencer SJ, Buller KM, Day TA (2005) Medial prefrontal cortex control of the paraventricular hypothalamic nucleus response to psychological stress: possible role of the bed nucleus of the stria terminalis. J Comp Neurol 481:363-376. CrossRef Medline

Sun QQ, Baraban SC, Prince DA, Huguenard JR (2003) Target-specific neuropeptide $\mathrm{Y}$-ergic synaptic inhibition and its network consequences within the mammalian thalamus. J Neurosci 23:9639-9649. Medline

Tu B, Timofeeva O, Jiao Y, Nadler JV (2005) Spontaneous release of neuropeptide $Y$ tonically inhibits recurrent mossy fiber synaptic transmission in epileptic brain. J Neurosci 25:1718-1729. CrossRef Medline

Verma D, Tasan RO, Herzog H, Sperk G (2012) NPY controls fear conditioning and fear extinction by combined action on $\mathrm{Y} 1$ and $\mathrm{Y} 2$ receptors. Br. J Pharmacol 166:1461-1473. CrossRef Medline

Verma D, Wood J, Lach G, Mietzsch M, Weger S, Heilbronn R, Herzog H, Bonaventure P, Sperk G, Tasan RO (2015) NPY Y2 receptors in the central amygdala reduce cued but not contextual fear. Neuropharmacology 99:665-674. CrossRef Medline

Vythilingam M, Gill JM, Luckenbaugh DA, Gold PW, Collin C, Bonne O, Plumb K, Polignano E, West K, Charney D (2010) Low early morning plasma cortisol in posttraumatic stress disorder is associated with comorbid depression but not with enhanced glucocorticoid feedback inhibition. Psychoneuroendocrinology 35:442-450. CrossRef Medline

Wu G, Feder A, Wegener G, Bailey C, Saxena S, Charney D, Mathé AA (2011) Central functions of neuropeptide $\mathrm{Y}$ in mood and anxiety disorders. Expert Opin Ther Targets 15:1317-1331. CrossRef Medline

Wulsin AC, Herman JP, Solomon MB (2010) Mifepristone decreases depression-like behavior and modulates neuroendocrine and central hypothalamic-pituitary-adrenocortical axis responsiveness to stress. Psychoneuroendocriology 35:1100-1112. CrossRef Medline

Zhang H, Sakharkar AJ, Shi G, Ugale R, Prakash A, Pandey SC (2010) Neuropeptide $\mathrm{Y}$ signaling in the central nucleus of the amygdala regulates alcohol-drinking and anxiety-like behaviors of alcohol-preferring rats. Alcohol Clin Exp Res 34:451-461. CrossRef Medline

Zhou Z, Zhu G, Hariri AR, Enoch MA, Scott D, Sinha R, Virkkunen M, Mash DC, Lipsky RH, Hu XZ, Hodgkinson CA, Xu K, Buzas B, Yuan Q, Shen PH, Ferrell RE, Manuck SB, Brown SM, Hauger RL, Stohler CS, Zubieta JK, Goldman D (2008) Genetic variation in human NPY expression affects stress response and emotion. Nature 452:997-1001. CrossRef Medline 